\title{
SISTEM INFORMASI ADMINISTRASI PINJAMAN (KREDIT) PADA CREDO UNION MODIFIKASI (CUM) BERBASIS WEB
}

\author{
Victor Marudut Mulia Siregar ${ }^{1)}$, Erikson Damanik' ${ }^{2}$, Mega Romauly Tampubolon ${ }^{3)}$, \\ Eve Ida Malau ${ }^{3)}$, Eka Pratiwi Septania Parapat ${ }^{3)}$, Debora Silvia Hutagalung ${ }^{3)}$ \\ ${ }^{1}$ Teknik Komputer, Politeknik Bisnis Indonesia \\ email: victor.siregar2@gmail.com \\ ${ }^{2}$ Komputerisasi Akuntansi, Politeknik Bisnis Indonesia \\ email: damanik.1969@gmail.com \\ ${ }^{3}$ Manajemen, Sekolah Tinggi Akuntansi dan Manajemen Indonesia \\ tampubolonmega75@gmail.com, evemalau@gmail.com, \\ ekapsparapat@gmail.com, hutagalungdebora@ymail.com
}

\begin{abstract}
Modified Union credo is a cooperative-type business entity owned by a group of people in a unifying bond, which agrees to invest their money (shares) so as to create joint capital with decent business results and for productive and welfare purposes. The role of cooperatives is very important in Indonesia, because cooperatives can increase the economic growth of Indonesian society. The loan administration information system (credit) at CUM Caritas HKBP Pematangsiantar is not yet effective, because it still uses a manual system so that data is easily lost and difficult to find, and the preparation of reports takes a long time. The purpose of this study is to build a system that makes it easier for staff to process data for CUM Caritas HKBP members and improve staff performance to be more efficient and minimize errors in data processing, especially in the loan administration (credit) section of CUM Caritas HKBP. In this research, in the process of collecting data, the researcher used the method of observation, interviews and literature study and the method of system development to be used was the Prototype method. The information system to be designed will be in the form of a web and use the MySQL database. It is hoped that this research can solve the problem of Loan Administration (Credit) at CUM Caritas HKBP Pematangsiantar.
\end{abstract}

Keywords : Loans, Cooperatives, Systems, Information, Credit

\section{PENDAHULUAN}

Kebutuhan akan informasi yang dijadikan sebagai dasar pengambilan keputusan di dalam setiap organisasi semakin dibutuhkan. Oleh karena itu semakin banyak pengambilan keputusan saat ini melibatkan penggunaan teknologi komputer dan sistem informasi [1] [10], [11]-[16]. Pemanfaatan teknologi pada perkembangannya sangat berperan dalam kehidupan [17]-[19], [20], [21].

Seiring dengan perkembangan zaman yang meningkatkan daya kreativitas manusia, menyebabkan banyak perkembangan ilmu pengetahuan dan teknologi yang cukup pesat. Salah satu perkembangannya adalah di bidang teknologi informasi. Dalam kemajuan teknologi informasi mempermudah penyediaan informasi sehingga segala permasalahan yang menyangkut tentang penyediaan informasi dapat diselesaikan secara efektif dan efisien [22], [23].
CUM Caritas HKBP Pematangsiantar adalah badan usaha yang dimiliki oleh sekumpulan orang dalam suatu ikatan pemersatu, yang tersepakat untuk menginventasikan uang (saham) mereka sehingga menciptakan modal bersama dengan hasil usaha yang layak serta untuk tujuan produktif dan kesejahteraan.

Saat ini proses pengajuan pinjaman kredit pada CUM Caritas HKBP masih menggunakan sistem yang manual dalam pengadministrasiannya, yaitu harus mencatat banyak hal secara manual di Microsoft excel dan beberapa kertas kerja untuk mendapatkan datadata anggota peminjam untuk diproses oleh pihak CUM.

Sistem yang manual ini menyebabkan data-data anggota yang ingin mengajukan pinjaman sangat sulit untuk dicari. Banyak keluhan dari anggota yang ingin mengajukan pinjaman dikarenakan data mereka hilang 
sehingga anggota harus mengisi ulang formulir pengajuan pinjaman disetiap peminjaman yang akan dilakukan. Proses yang dilakukan secara manual ini juga mengakibatkan pihak CUM sering mengalami kendala terutama kesalahan dalam perhitungan jasa pinjaman yang sangat menyita banyak waktu dan memiliki resiko kesalahan yang besar. Apabila Hal ini dilakukan dengan kurang teliti maka akan mempengaruhi pendapatan biaya operasional yang nantinya digunakan untuk keberlangsungan berdirinya CUM Caritas HKBP. Selain itu, permasalahan tersebut juga mengakibatkan data anggota sering menjadi ganda (berulang) dan riwayat dari pinjaman anggota tersebut tidak jelas dikarenakan data masing-masing anggota tidak tersimpan dengan baik.

Berdasarkan uraian di atas untuk mengatasi permasalahan tersebut, maka dirancang sebuah sistem informasi yang dapat membantu mempermudah pihak CUM Caritas HKBP untuk meningkatkan pelayanannya dalam pengelolahan data pinjaman (kredit). Sistem yang dirancang ini mampu meminimalkan kesalahan dalam pengolahan data administrasi pinjaman (kredit) pada CUM HKBP. Dengan sistem ini penginputan, pengecekan informasi, serta mengahasilkan laporan-laporan pinjaman data anggota CUM Caritas HKBP menjadi lebih cepat dan akurat. Penginputan data pada sistem yang terdiri dari data anggota, data pinjaman, data cicilan/angsuran pinjaman anggota CUM Caritas HKBP dapat dilakukan dengan mudah. Pembuatan laporan juga dapat dibuat dengan cepat seperti laporan daftar anggota CUM Caritas HKBP, laporan data statistik pinjaman (kredit), laporan data pengajuan pinjaman (kredit), laporan jatuh tempo pinjaman (kredit). Sistem ini dibuat dengan menggunakan bahasa pemrograman PHP, Javascript dan CSS.

\section{METODE PENELITIAN}

Sistem Informasi yang dirancang, dikembangkan menggunakan model Prototype dikarenakan pemodelan cepat dalam pengembangannya serta dapat mengidentifikasi kebutuhan dan keinginan pemakai secara langsung saat model yang dirancang telah selesai dibuat, sehingga pengembang dapat mengerti apa keinginan dari pengguna sistem.
Langkah-langkah dalam pengembangan sistem prototype yang dilakukan antara lain :

1. Communication : Komunikasi dilakukan antara pengembang sistem dan pihak CUM Caritas HKBP Pematangsiantar mengenai masalah yang dihadapi saat menggunakan sistem yang berjalan.

2. Quick Plan: Setelah dilakukan komunikasi dengan cara wawancara kepada pihak CUM Caritas, maka dilakukan quick plan atau perencanaan secara cepat untuk memberikan suatu usulan sistem baru yang dapat memberikan jalan keluar dari masalahmasalah yang ditemukan, yaitu dengan membuat Sistem Informasi Administrasi Pinjaman Kredit CUM Caritas HKBP Pematangsiantar Berbasis Web.

3. Modeling, Quick Design: Setelah quick plan disetujui oleh pihak CUM, lalu dilakukan pemodelan sistem dengan menggunakan diagram Data Flow Diagram, Entity Relationship Diagram dan Struktur Tabel sebagai rancangan dari database sistem dan rancangan antarmuka sistem.

4. Construction of prototype : Setelah pemodelan sistem dan perancangan antarmuka selesai, maka rancangan yang telah selesai dilakukan akan diimplementasikan kedalam sebuah prototipe Sistem Informasi Administrasi Pinjaman Kredit CUM Caritas HKBP Pematangsiantar Berbasis Web.

5. Deployment, Delivery \& Feedback : Setelah Prototipe pertama selesai, maka prototipe akan diuji coba oleh pihak CUM Caritas, untuk mengetahui apakah prototipe yang telah dibangun sesuai dengan keinginan oleh pihak CUM Caritas, jika prototipe belum sesuai, maka prototipe akan dikembangkan lagi sesuai dengan kritik atau masukan dari pihak CUM Caritas, jika prototipe sesuai dan disetujui oleh pihak CUM Caritas, maka prototipe yang telah disetujui merupakan bentuk akhir dari sistem yang diusulkan.

Perancangan sistem informasi administrasi pinjaman kredit ini dilakukan dengan tahapan :

\subsection{Perancangan Diagram Konteks}

Diagram konteks administrasi peminjaman kredit CUM Caritas HKBP Pematangsiantar 
terdiri atas 3 entitas yaitu anggota, staf, dan manager. Perancangan Diagram Konteks seperti pada gambar 1 .

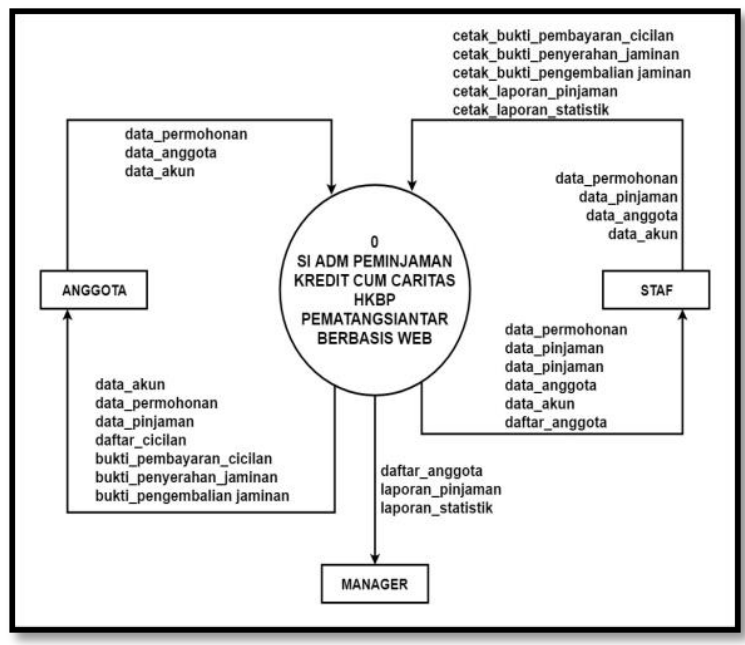

Gambar 1. Diagram Konteks

\subsection{Perancangan Database}

Rancangan database berupa ERD untuk sistem informasi administrasi pinjaman kredit CUM Caritas HKBP Pematangsiantar, dapat dilihat pada Gambar 2.

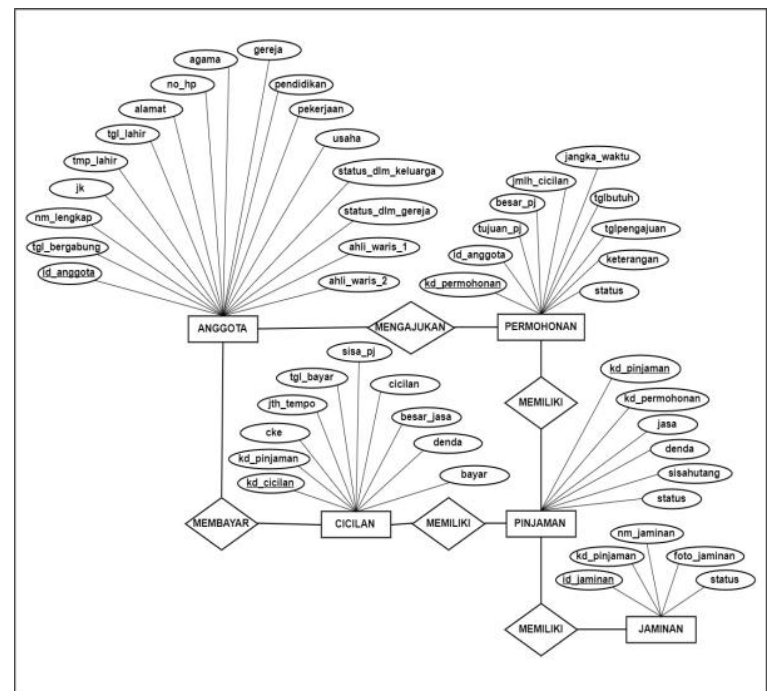

Gambar 2. ERD (Entity Relationship Diagram)

\subsection{Perancangan Antarmuka \\ Perancangan Antarmuka terdiri dari :}

a. Rancangan Halaman Data Anggota
Hasil rancangan halaman data anggota dapat dilihat pada Gambar 3.

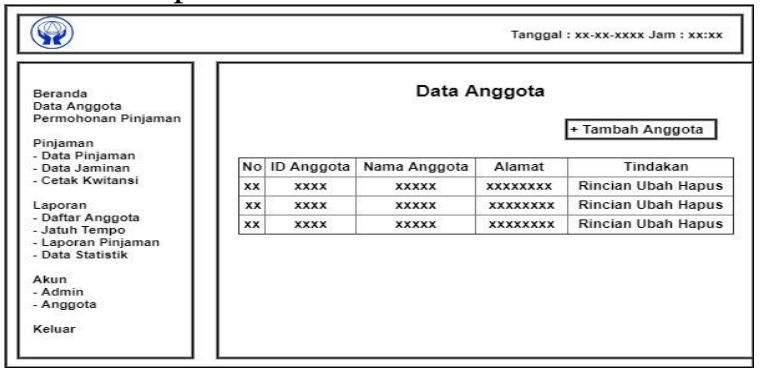

Gambar 3. Rancangan Antarmuka Halaman Data Anggota

b. Rancangan Halaman Input Anggota Baru Hasil rancangan halaman input anggota baru dapat dilihat pada Gambar 4.

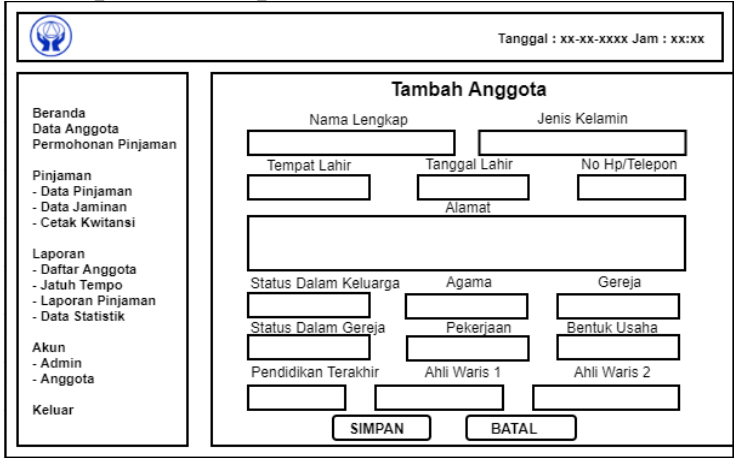

Gambar 4. Rancangan Antarmuka Halaman Input Anggota baru

c. Rancangan Halaman Data Pinjaman Hasil rancangan halaman Data Pinjaman dapat dilihat pada Gambar 5.

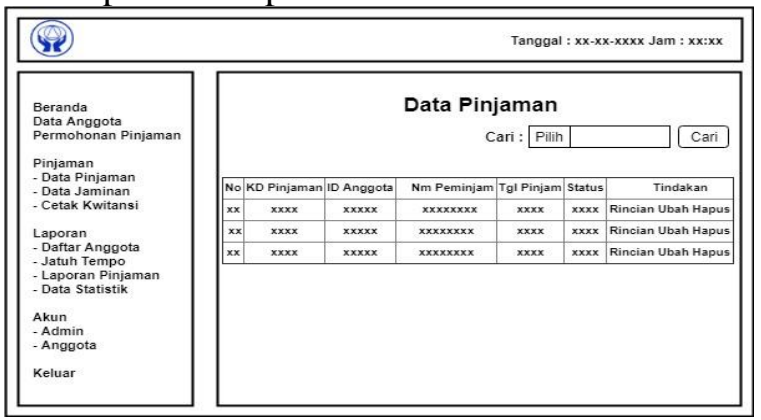

Gambar 5. Rancangan Antarmuka Halaman Data Pinjaman

d. Rancangan Halaman Input Angsuran Hasil rancangan halaman input Angsuran dapat dilihat pada Gambar 6. 


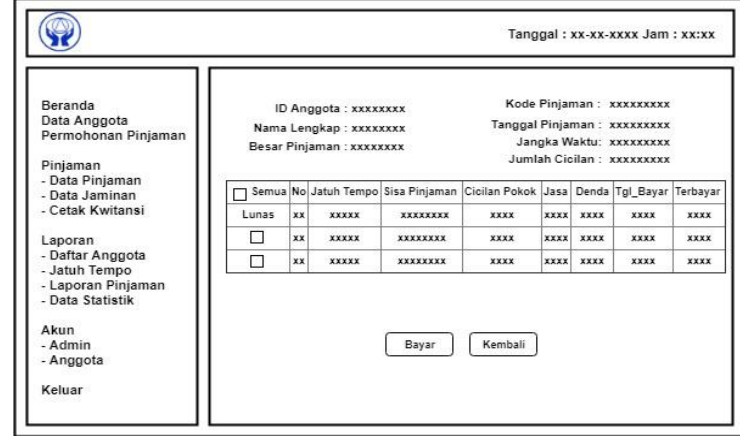

Gambar 6. Rancangan Antarmuka Halaman Input Anggota baru

e. Rancangan Halaman Riwayat Cicilan Hasil rancangan halaman Riwayat Cicilan dapat dilihat pada Gambar 7.

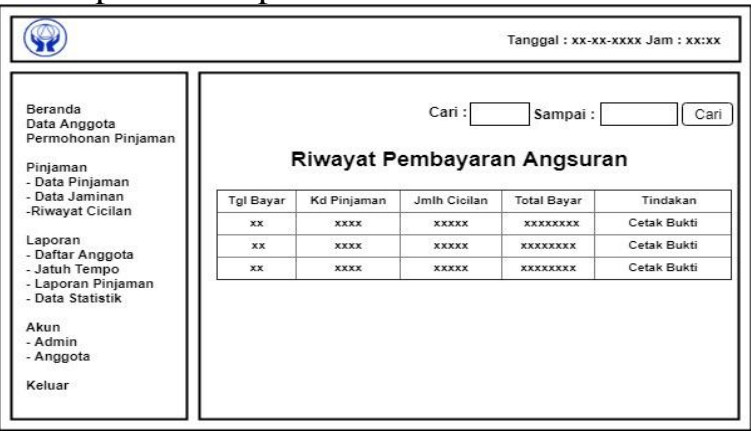

Gambar 7. Rancangan Antarmuka Halaman Input Anggota baru

f. Rancangan Halaman Beranda Anggota Hasil rancangan halaman Beranda Anggota dapat dilihat pada Gambar 8 .

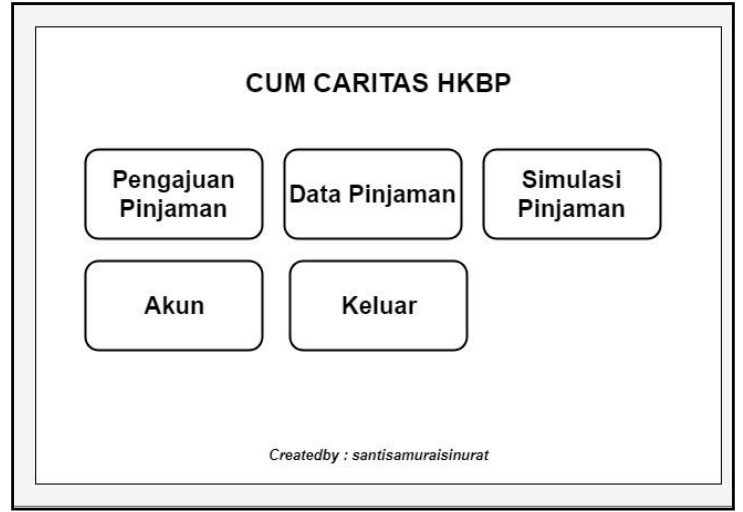

Gambar 8. Rancangan Antarmuka Halaman Beranda Anggota

g. Rancangan Halaman Pengajuan Pinjaman Hasil rancangan halaman Pengajuan Pinjaman dapat dilihat pada Gambar 9.

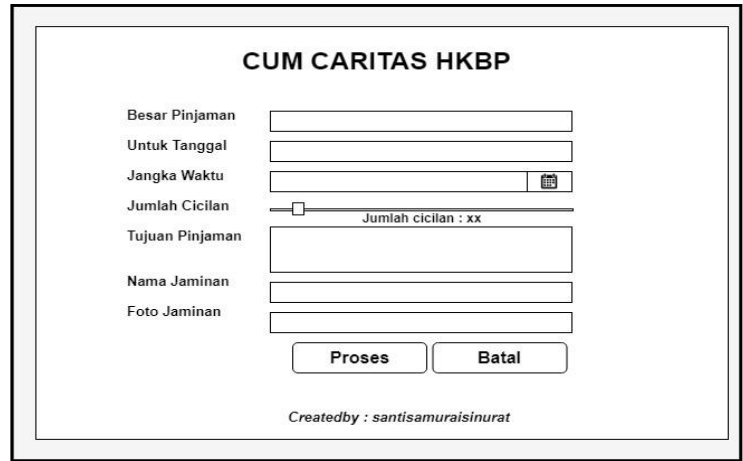

Gambar 9. Rancangan Antarmuka Halaman Pengajuan Pinjaman

h. Rancangan Halaman Data Pinjaman Hasil rancangan halaman Pengajuan Pinjaman dapat dilihat pada Gambar 10.

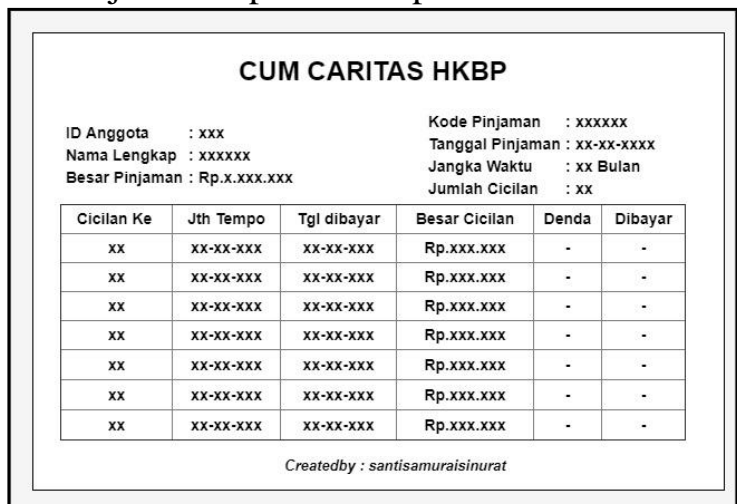

Gambar 10. Rancangan Halaman Data Pinjaman

i. Rancangan Halaman Simulasi Pinjaman Hasil rancangan halaman Simulasi Pinjaman dapat dilihat pada Gambar 11.

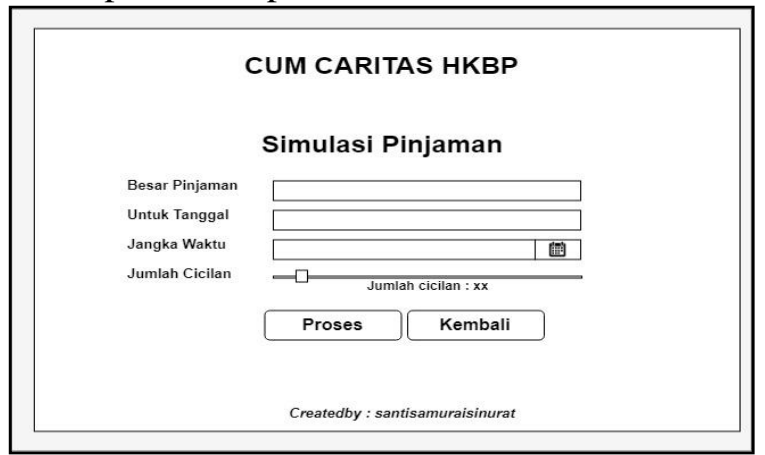

Gambar 11. Rancangan Antarmuka Halaman Simulasi Pinjaman

\section{HASIL DAN PEMBAHASAN}

Hasil implementasi dari sistem informasi administrasi pinjaman (kredit) Cum Caritas HKBP terdiri dari : 


\subsection{Halaman Data Anggota}

Halaman data anggota berisi tentang data-data anggota CUM Caritas, mulai dari nama, alamat, jenis kelamin, dan melihat rincian data anggota. Staf dapat menambah, mengubah dan menghapus data anggota di halaman ini. Implementasi halaman data anggota dapat dilihat pada Gambar 12.

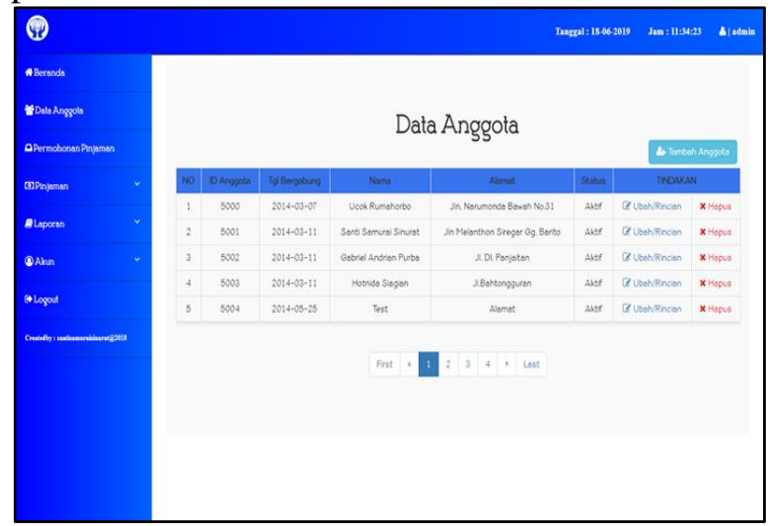

Gambar 12. Implementasi Halaman Data Anggota

\subsection{Halaman Permohonan Pinjaman}

Halaman permohonan pinjaman menampilkan data-data permohonan pinjaman yang telah diajukan oleh anggota Cum Caritas. Berikut adalah implementasi halaman Permohonan Pinjaman, dapat dilihat pada Gambar 13.

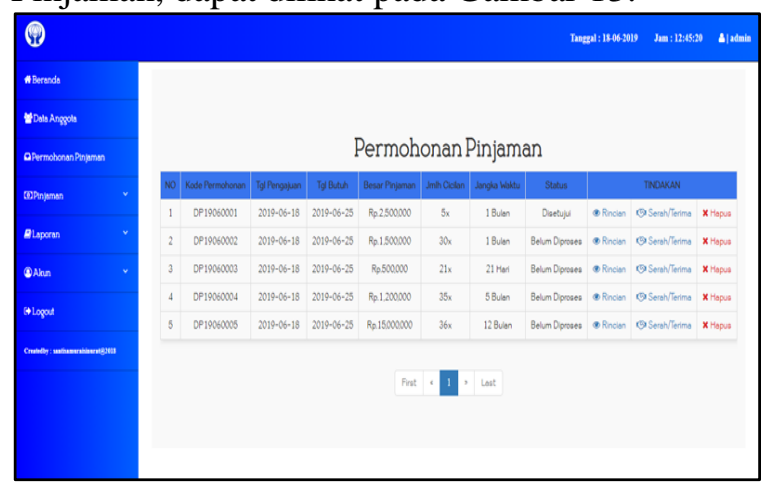

Gambar 13. Implementasi Halaman Permohonan Pinjaman

\subsection{Halaman Data Pinjaman}

Halaman data pinjaman menampilkan data-data pinjaman anggota Cum Caritas yang berjalan maupun yang telah lunas. Staf (Admin) dapat melakukan pencarian secara cepat menurut kode pinjaman maupun id anggota. Implementasi halaman data pinjaman dapat dilihat pada Gambar 14.

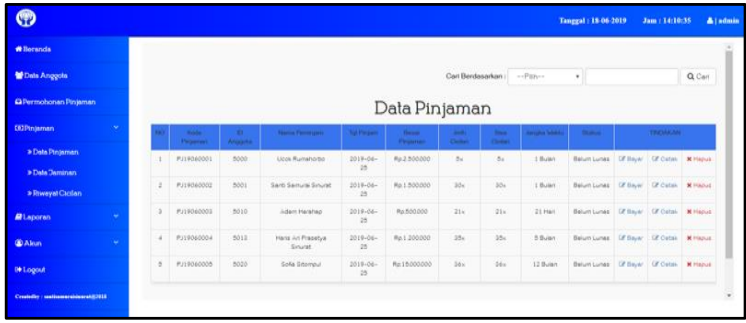

Gambar 14. Implementasi Halaman Data Pinjaman

\subsection{Halaman Riwayat Pembayaran Cicilan} Halaman Riwayat Pembayaran menampilkan riwayat dari pembayaran cicilan pinjaman yang telah dilakukan oleh anggota. Pada halaman ini staf (admin) dapat mencetak bukti pembayaran cicilan.

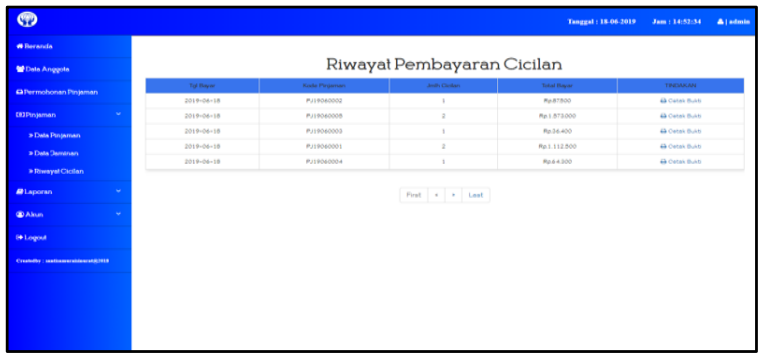

Gambar 15. Implementasi Halaman Riwayat Pembayaran

\subsection{Halaman Data Akun Anggota}

Halaman ini menampilkan data-data akun yang dipakai anggota untuk masuk kedalam sistem yang terdiri dari username dan password. Staf (Admin) dapat melakukan pencarian data akun menurut id anggota maupun username akun. Implementasinya dapat dilihat pada Gambar 16.

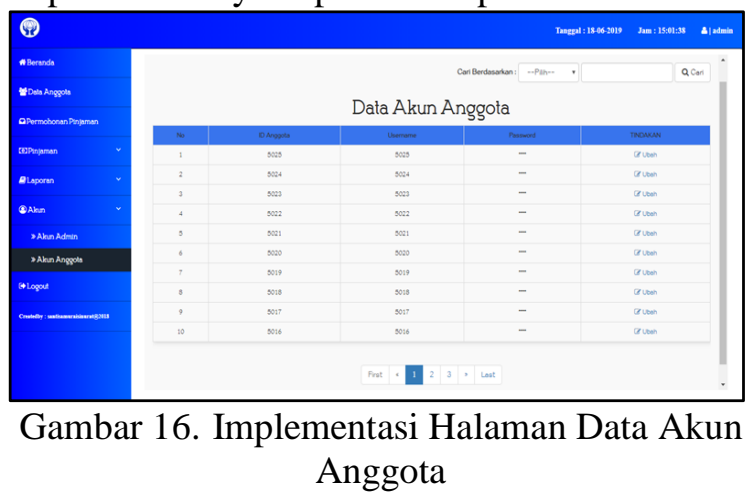

\subsection{Halaman Input Tambah Anggota}

Halaman input tambah anggota merupakan halaman untuk menginput data anggota baru pada sistem seperti pada Gambar 17. 


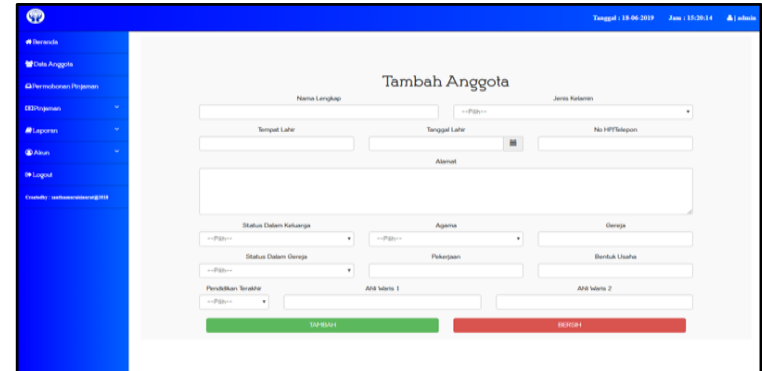

Gambar 17. Implementasi Halaman Input Tambah Anggota

\subsection{Halaman Input Bayar Cicilan}

Halaman input bayar cicilan adalah halaman yang digunakan staf untuk menginput data pembayaran cicilan pinjaman anggota, staf dapat memilih cicilan yang akan dibayar dengan mencentang chekbox cicilan, sesuai dengan cicilan yang ingin dibayar.

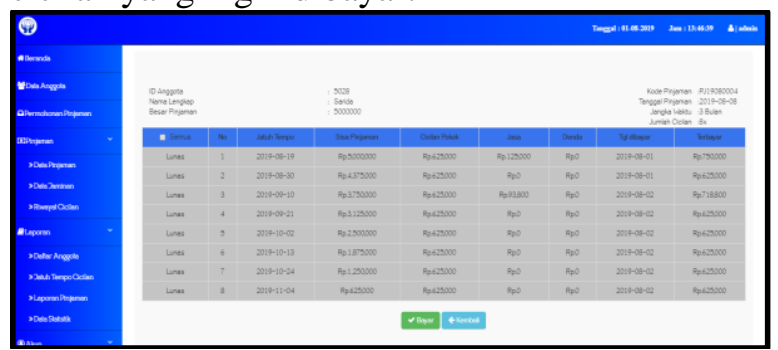

Gambar 18. Implementasi Halaman Input Bayar Cicilan

\subsection{Halaman Laporan Daftar Anggota}

Halaman laporan anggota digunakan staf untuk mencetak anggota yang masih aktif di Cum Caritas HKBP. Staf dapat mencetak daftar anggota dengan mengklik tombol cetak daftar anggota.

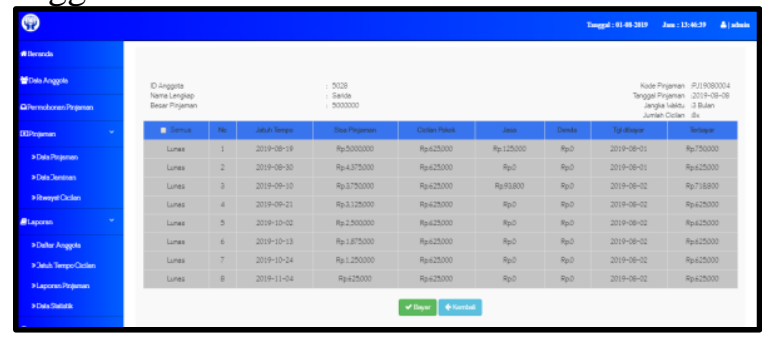

Gambar 19. Implementasi Halaman Laporan Daftar Anggota

\subsection{Halaman Laporan Jatuh Tempo}

Halaman laporan jatuh tempo menampilkan laporan daftar jatuh tempo dari setiap cicilan pinjaman anggota, sesuai dari tanggal yang diinput oleh staf. Berikut adalah hasil implementasi halaman laporan jatuh tempo.

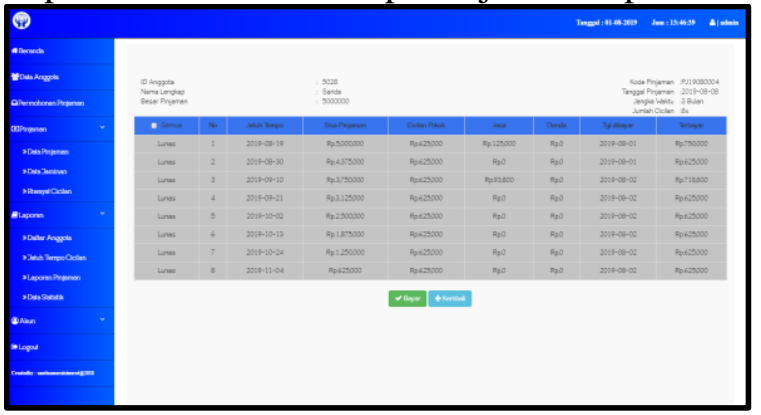

Gambar 20. Implementasi Halaman Laporan Jatuh Tempo

\subsection{Halaman Laporan Pinjaman}

Halaman laporan pinjaman merupakan bagian dari sistem pelaporan CUM yang ditujukan untuk pihak internal maupun eksternal CUM yang mempengaruhi keadaan keuangan CUM dalam jangka pendek dan jangka panjang.

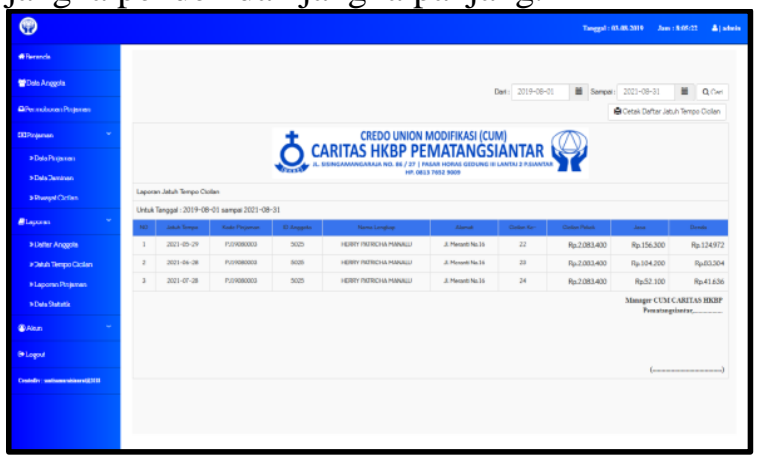

Gambar 21. Implementasi Halaman Laporan Pinjaman

\subsubsection{Halaman Input Simulasi Pinjaman} Halaman input simulasi pinjaman merupakan halaman yang berguna untuk anggota dapat mensimulasikan pinjaman, agar dapat melihat seberapa besar nantinya cicilan yang harus dibayarkan. Berikut adalah hasil implementasi halaman input simulasi pinjaman.

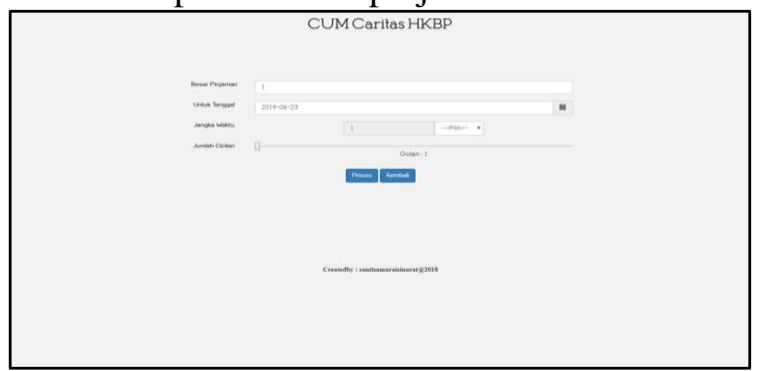

Gambar 22. Implementasi Halaman Input Simulasi Pinjaman 
3.11. Halaman Laporan Statistik Pinjaman Halaman laporan statistik pinjaman merupakan halaman untuk mencetak laporan statistik pinjaman yang berjalan di CUM. Hasil implementasinya dapat dilihat pada gambar 23.

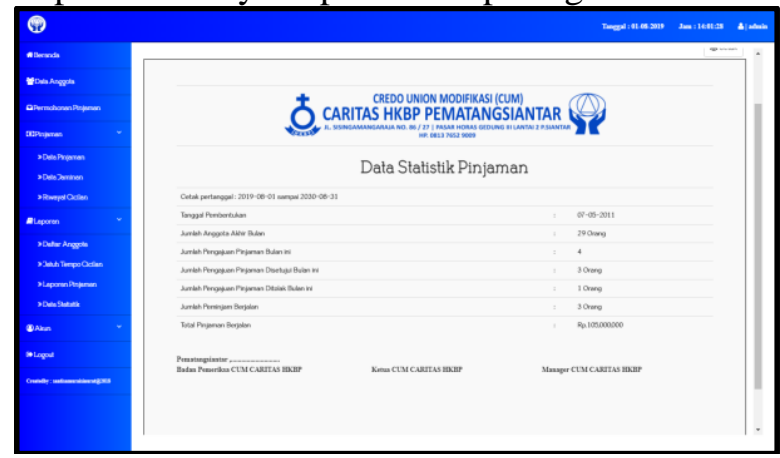

Gambar 23. Implementasi Halaman Laporan Statistik Pinjaman

\section{KESIMPULAN}

Dari hasil implementasi Sistem Informasi Administrasi Pinjaman (Kredit) Berbasis Web yang dibangun, dapat diambil kesimpulan sebagai berikut:

1. Sistem Informasi Administrasi Pinjaman (Kredit) berbasis web ini dapat membantu mempermudah pihak CUM Caritas HKBP Pematangsiantar dalam pengolahan dan pengarsipan data administrasi pinjaman (kredit).

2. Dengan adanya Sistem Informasi Administrasi Pinjaman (Kredit) berbasis web ini pekerjaan para staf dalam pengolahan data pinjaman dan pembuatan laporan dapat dilakukan dengan lebih efisien dan efektif.

\section{REFERENSI}

[1] J. Simatupang and S. Sianturi, "PERANCANGAN SISTEM INFORMASI PEMESANAN TIKET BUS PADA PO. HANDOYO BERBASIS ONLINE," J. Intra Tech, vol. 3, no. 2, pp. 11-25, 2019.

[2] V. Sihombing and G. J. Yanris, "PENERAPAN APLIKASI DALAM MENGOLAH ASET DESA (STUDI KASUS: KEPENGHULUAN SRI KAYANGAN)," J. Mantik Penusa, vol. 4, no. 1, pp. 12-15, 2020.

[3] V. Sihombing, "Aplikasi Simade (Sistem
Informasi Manajemen Desa) Dalam Meningkatkan Pelayanan Administrasi di Kepenghuluan Bakti Makmur Kecamatan Bagan Sinembah Kab. Rokan Hilir Riau," SISTEMASI, vol. 7, no. September, pp. 292-297, 2018.

[4] J. Simatupang, "Perancangan Sistem Inventori Barang pada Toko Nichos Jaya Menggunakan Metode FIFO," J. Intra Tech, vol. 1, no. 1, pp. 31-42, 2017.

[5] V. Sihombing, "Sistem Informasi Penjualan Mobil Suzuki Di Dealer Bagan Batu," SISTEMASI, vol. 7, no. 2, pp. 113119, 2018.

[6] W. Purba, S. Aisyah, and S. P. Tamba, "Perancangan Sistem Pakar Diagnosa Penyakit Mata Katarak Menggunakan Konsep Metode Runut Mundur," JUSIKOM PRIMA (Junal Sist. Inf. Ilmu Komput. Prima), vol. 1, no. 1, 2017.

[7] G. J. Yanris, "Analisis Dan Implementasi Data Mining Dalam Menganalisa Kendala Akademik Yang Sering Dikeluhkan Mahasiswa AMIK Labuhanbatu (Studi Kasus : Amik Labuhanbatu)," Informatika, vol. 4, no. 1, pp. 15-24, 2016.

[8] Fricles Ariwisanto Sianturi, "Analisa metode teorema bayes dalam mendiagnosa keguguran pada ibu hamil berdasarkan jenis makanan," Tek. Inf. dan Komput., vol. 2, no. 1, pp. 87-92, 2019.

[9] A. Ardian, I. Purnama, and V. Sihombing, "Perancangan Aplikasi Pengolah Data Siswa Berbasis Android (Studi Kasus: Mis Nurul Huda Labuhan Batu Selatan)," Pengabdi. Masy. Ika Bina En Pabolo, vol. 1, no. 1, pp. 40-53, 2019.

[10] W. Purba, S. Tamba, and J. Saragih, "The effect of mining data k-means clustering toward students profile model drop out potential," J. Phys. Conf. Ser., vol. 1007, no. 1, p. 12049, 2018.

[11] V. M. Siregar, H. Sugara, and G. A. Purba, "APLIKASI PENCATATAN LAPORAN PENJUALAN KITA-KITA. NET BERBASIS WEB," J. Tek. Inf. dan Komput., vol. 2, no. 1, pp. 80-86, 2019.

[12] H. A. Simbolon and V. M. M. Siregar, "Perancangan Sistem Informasi Berbasis E-Commerce Untuk Peningkatan 
Penjualan Produk Jersey Olah Raga," J. Tek. Inf. dan Komput., vol. 1, no. 2, pp. 49-54, 2018.

[13] V. M. Siregar and H. Sugara, "Perancangan Dan Implementasi Aplikasi Penggajian Berbasis Dekstop Pada Murni Sadar English Course," J. Tek. Inf. dan Komput., vol. 1, no. 2, pp. 42-48, 2018.

[14] V. M. M. Siregar, H. Sugara, and I. M. Siregar, "Perancangan Sistem Informasi Pendataan Barang Pada PT. Serdang Hulu," J. Comput. Bisnis, vol. 12, no. 2, pp. 111-117, 2018.

[15] V. M. M. Siregar, "Sistem Pendukung Keputusan Penentuan Insentif Bulanan Pegawai Dengan Menggunakan Metode Naïve Bayes," SISTEMASI, vol. 7, no. 2, pp. 87-94, 2018.

[16] V. M. M. Siregar, "Perancangan Sistem Informasi Inventaris Barang Pada Sekolah SMA Negeri 4 Pematangsiantar," IT J. Res. Dev., vol. 3, no. 1, pp. 54-61, 2018.

[17] P. Dani Prasetyo Adi and A. Kitagawa, "A performance of radio frequency and signal strength of LoRa with BME280 sensor," TELKOMNIKA (Telecommunication Comput. Electron. Control., vol. 18, no. 2, p. 649, Apr. 2020.

[18] P. D. P. Adi and A. Kitagawa, "ZigBee Radio Frequency (RF) performance on Raspberry Pi 3 for Internet of Things (IoT) based blood pressure sensors monitoring," Int. J. Adv. Comput. Sci. Appl., 2019.

[19] P. Adi, D. Prasetya, A. Setiawan, N. Nachrowie, and R. Arifuddin, "Design Of Tsunami Detector Based Sort Message Service Using Arduino and SIM900A to GSM/GPRS Module," Proc. Proc. 2nd Int. Conf. Adv. Sci. Innov. ICASI 2019, 18 July, Banda Aceh, Indones., 2019.

[20] S. P. Tamba, M. D. Batubara, W. Purba, M. Sihombing, V. M. Mulia Siregar, and J. Banjarnahor, "Book data grouping in libraries using the k-means clustering method," J. Phys. Conf. Ser., vol. 1230, no. 1, p. 012074, Jul. 2019.

[21] V. M. M. Siregar, H. Sugara, and G. A. Purba, "Aplikasi Pencatatan Laporan Penjualan Kita-Kita.Net Berbasis Web," TEKINKOM, vol. 2, no. 1, pp. 80-86,
2019.

[22] A. T. Purba and V. M. M. Siregar, "Sistem Penyeleksi Mahasiswa Baru Berbasis Web Menggunakan Metode Weighted Product," TEKINKOM, vol. 3, no. 1, pp. $1-8,2020$.

[23] S. S. S, A. T. Purba, and V. M. M. Siregar, "Sistem Penyeleksi Mahasiswa Baru Berbasis Web Menggunakan Metode Weighted Product," J. Tek. Inf. dan Komput., vol. 3, no. 1, p. 1, Sep. 2020. 